\title{
簡易型多機能トイレの最小空間寸法に関する研究 A STUDY ABOUT MINIMUM SPACE MEASUREMENTS OF SIMPLIFIED MULTI-FUNCTIONAL TOILETS
}

\author{
竜口隆三*, 高橋儀平**, 田村房 義*** \\ Ryuzo TATSUGUCHI, Gihei TAKAHASHI and Fusayoshi TAMURA
}

\begin{abstract}
Under the new legislation for the promotion of barrier-free environments, people with mental retardation, psychiatric disorder and developmental impairment are added to the user list of all barrier-free facilities. This amplification of users has brought about new problems for the current public toilets as well. The only multi-functional room can not meet the various needs of all users and wheel chair users are demanding for more user-friendlily private rooms to their convenience. This study conducts verification experiments for a minimum measurement of newly-designed private rooms for wheelchair users and suggests that the ideal space should be kept at a scale of $1,150 \sim 1,250 \mathrm{~mm} \times 1,900 \sim 2,000 \mathrm{~mm}$ within a public toilet.
\end{abstract}

Keywords : Public rest room, Wheelchair user, Simplified multi-functional, Space measurements, User testing 公共トイレ，車い寸使用者，簡易多機能，空間寸法，ユーザー検証

1. はじめに

多機能トイレ注1)の普及により障害者等の社会参加が促進される 一方、複数の多機能トイレの設置は困難というのが現状である。ま たユニバーサルデザインの思想が浸透するに伴い、多機能トイレが 車い寸使用者はもちろん、乳幼児連れ・オストメイト（人工肛門他） や高齢者に利用される機会が増えてきており、その結果車い寸使用 者から「多機能トイレを利用できない」「多機能トイレの絶対数が不 足している」等の声が上がり問題が生じている。こうした問題解決 のために、バリアフリー新法による建築設計標準注 2)では、車い寸 使用者用トイレに加え男女トイレにそれぞれ広めの一般トイレブー ス（以下簡易型多機能トイレ）を設置することが推奨されている。

簡易型多機能卜イレ注3) とは従来の一般ブースよりやや広めの大 便器ブースで、車い寸使用者が利用できるもので、既存の大便器の 便房を改造することによって設置できる利点があることから今後普 及が進むと考える。既往研究では、公共トイレの多機能トイレブー スの空間の評価 1)。2) や壁面に設置する機器や手すりの利便性 3)。4)。5) 床面積や形状違いによる照度の変化 ${ }^{6)}$ に関する研究は行われている が、簡易型多機能トイレの最小空間寸法についての研究は今後の課 題である。

そこで本研究では、簡易型多機能トイレの普及を目指し、車い寸
使用者の身体状況の相違や車い寸の種別等必要最低条件を考慮し、 利用可能な空間寸法の検証を行うこととした。

\section{2. 研究の目的}

一般トイレ内に設けられる簡易型多機能卜イレは、多機能卜イレ と異なり、平面配置計画上も十分に余裕のあるスペースの確保が難 しいと考えられ、設計者や施工者は適正なブースの大きさや形状に 苦慮している。現状の簡易型多機能トイレは以下のような形状・ス ペースで示されることが多い（図 1)。

だが、このトイレを使用するユーザーの根拠が不明確であること、

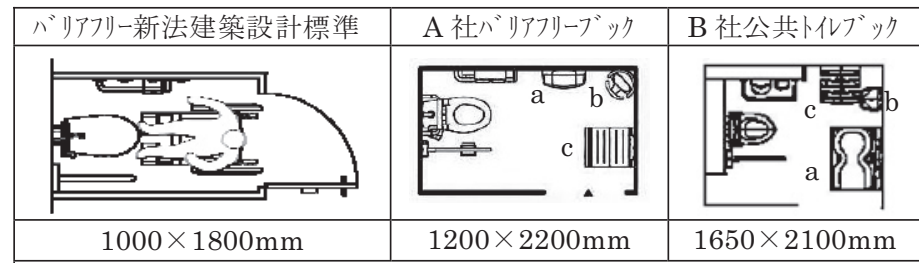

簡易型多機能卜イレは車い寸使用者のほかに赤ちゃん連れの方も使 用することを配慮し、 $\mathrm{A}$ 社・B 社の図面には「 $\mathrm{a}$ ：乳児用ベッド」「b：

乳児用いす」「c：着替え台」等が設置されている。

図 1 簡易型多機能トイレプランの代表事例

\footnotetext{
* 東洋大学大学院福祉社会デザイン研究科 博士後期課程

** 東洋大学人間環境デザイン学科 教授・博士 (工学)

*** TOTO (株) UD 研究所 主幹
}

Graduate Student, Welfare Society Design, Toyo Univ.

Prof., Dept. of Human Environment Design, Toyo Univ., Dr. Eng.

Senior Researcher, Universal Design Research, TOTO Ltd. 
また簡易型多機能トイレ内に設置される設備器具が市販されている 物に限定され、結果寸法が決まることが多く明確な根拠があるとは 言えない。そこで本研究では基本動作である、扉閉め $\rightarrow$ 施錠 $\rightarrow$ 便器 へのアプローチ $\rightarrow$ 開錠 $\rightarrow$ 扉開け $\rightarrow$ 退室までの一連の行為の中で、ど の程度のスペースがあればこれらの行為が可能なのか、障害別・車 い寸種類別に利用可能な空間寸法を求めることを研究目的としてい る。

\section{3. 検証方法}

\section{（1）検証方法と検証装置}

簡易型多機能トイレは、以下のようなプラン（図 2）で設置され ていることが多いことから、出入口は短辺（間口）側出入口と長辺 （奥行）側出入口の 2 タイプと仮定し、また扉はレイアウト上から 短辺側は片開き戸、長辺側は片引き戸とし、可変壁ユニットと組み 合わせることにより、 $50 \mathrm{~mm}$ ピッチでブースの短辺及び長辺の寸法 を変化させることができる空間検証装置とした（写真 1 、図 2 )。 なお片開き戸は吊元側に $50 \mathrm{~mm}$ の支柱を設け、丁番で扉 $(\mathrm{t}=40 \mathrm{~mm})$ を固定し、有効開口幅 $800 \mathrm{~mm}$ 注4)確保を今回の検証の条件とした。 また扉両面に $\mathrm{L}=600 \mathrm{~mm}$ の横型握りバーを取り付けた。 長辺側片引き戸は入室後の便器へのアプローチを考慮（90 屈曲） し、有効開口幅 $900 \mathrm{~mm}$ 注 4 )確保を今回の検証の条件とした。

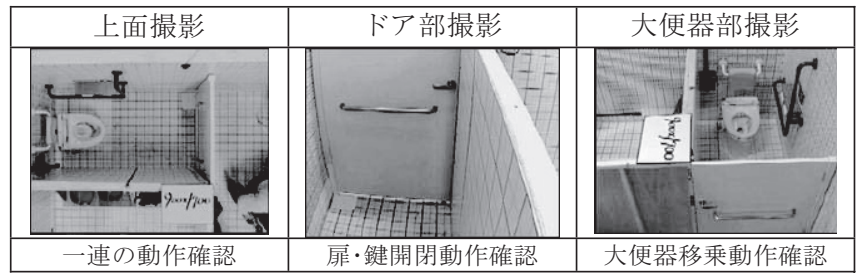

写真 1 検証装置と撮影個所
なお被験者の一連の行為を観察するために、上面からの VTR 撮 影と、扉及び鍵の開閉操作を確認するため便器上方から、大便器へ の移乗動作を確認するため扉上方から詳細撮影を行うことにした。

\section{（2）検証日時 ·場所 · 対象者}

(1)検証期間：第 1 回 平成 20 年 1 月 15 日 2 月 27 日 第 2 回 平成 20 年 9 月 16 日 9 月 24 日

(2)検証場所 : 北九州市内 $\mathrm{A}$ 社研究所の実験施設を使用 (3)対象：車い寸使用者 16 名

(第 1 回 : 16 名、第 2 回 : 10 名で第 1 回と重複者)

障害別・車い寸別被験者数並びに車い寸の詳細寸法は表 1 に示す。 被験者は移動が自立している車い寸使用者を 16 名選び、普段の外 出先を想定してもらい、服装・履物は自由とした。

なお被験者の半数が脳性まひ者となっているが、脊髄損傷の方に 比べ車い寸の動線や立ち上がり動作の幅が大きいことから、被験者 の割合を高めた（表 2 ）。

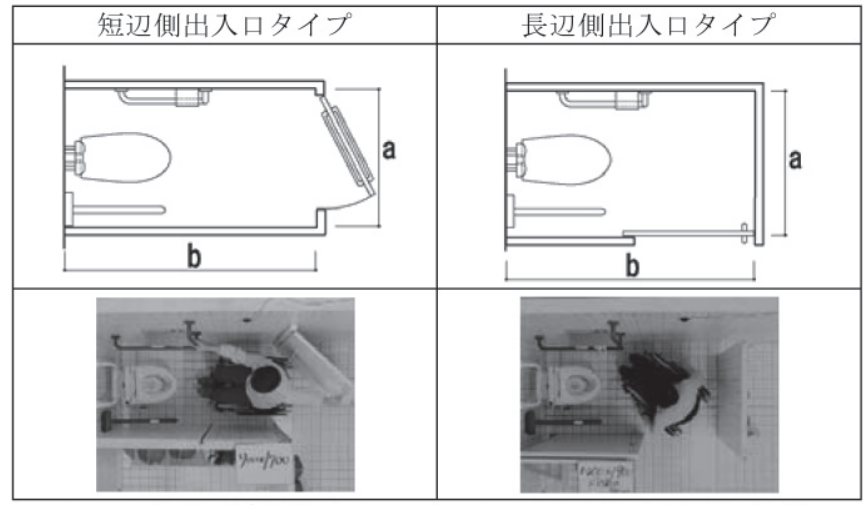

図 2 簡易型多機能トイレのレイアウト図と空間検証装置

表 1 調査対象者の概要

\begin{tabular}{|c|c|c|c|c|c|c|c|c|}
\hline 障害名 & \multicolumn{8}{|c|}{ 脳性まひ } \\
\hline 被験者 No & (1) & (2) & (3) & (4) & (5) & (6) & (7) & $(8)$ \\
\hline 年齢（性別） & 38 (男) & 46 (男) & 52 (男) & 32 (男) & 49 (男) & 55 (男) & 25 (男) & 43 (女) \\
\hline 移動方法 & J I S 自走 & J I S 自走 & J I S 自走 & J I S 自走 & J I S 自走 & J I S 自走 & 電動式 & 電動式 \\
\hline 車い寸最大長 & 695 & 1060 & 975 & 1030 & 900 & 1030 & 1045 & 1040 \\
\hline 車い寸最大幅 & 600 & 580 & 575 & 660 & 570 & 585 & 530 & 575 \\
\hline 乗車時最大長 ${ }^{\text {注 5) }}$ & 820 & 965 & 1230 & 1300 & 1090 & 1060 & 1045 & 1045 \\
\hline 乗車時最大幅注 5) & 600 & 630 & 575 & 760 & 615 & 755 & 595 & 600 \\
\hline 障害の状沉 & $\begin{array}{l}\text { 四肢体幹機 } \\
\text { 能障害 } \\
\text { 左手使用不 } \\
\text { 可：足こぎ }\end{array}$ & $\begin{array}{l}\text { 四肢体幹機 } \\
\text { 能障害 } \\
\text { 立ち上って } \\
\text { も円背状態 }\end{array}$ & $\begin{array}{l}\text { 四肢体幹機 } \\
\text { 能障害 } \\
\text { 左手使用不 } \\
\text { 可: 足こぎ }\end{array}$ & $\begin{array}{l}\text { 両下肢まひ } \\
\text { アームレストをプ } \\
\text { ッシュアップし } \\
\text { 立ち上り可 }\end{array}$ & $\begin{array}{l}\text { アテトーゼ型四 } \\
\text { 肢まひ } \\
\text { 上肢の力が } \\
\text { 異常に強い }\end{array}$ & $\begin{array}{l}\text { 両下肢まひ } \\
\text { 立ち上がり } \\
\text { 可 }\end{array}$ & $\begin{array}{l}\text { 四肢まひ } \\
\text { L型手すり } \\
\text { を使って立 } \\
\text { ち上り可 }\end{array}$ & $\begin{array}{l}\text { 四肢体幹機 } \\
\text { 能障害 } \\
\text { 縦手すりで } \\
\text { 立ち上り可 }\end{array}$ \\
\hline
\end{tabular}

\begin{tabular}{|c|c|c|c|c|c|c|c|c|}
\hline 障害名 & 脳血管障害 & \multicolumn{6}{|c|}{ 脊䯣損傷 } & 筋ジス \\
\hline 被験者No & (9) & (10) & (11) & (12) & (13) & (14) & (15) & (16) \\
\hline 年齢（性別） & 58 (男) & 48 (男) & 40 (男) & 38 (男) & 60 (男) & 36 (男) & 32 (女) & 36 (男) \\
\hline 移動方法 & J I S 自走 & モジュール & モジュール & モジュール & モジュール & モジュール & モジュール & J I S 自走 \\
\hline 車いす最大長 & 730 & 850 & 850 & 850 & 790 & 880 & 820 & 1010 \\
\hline 車い寸最大幅 & 590 & 565 & 555 & 525 & 495 & 590 & 540 & 655 \\
\hline 乗車時最大長 ${ }^{2}$ 5) & 890 & 975 & 850 & 920 & 890 & 995 & 920 & 1050 \\
\hline 乗車時最大幅注 5) & 665 & 830 & 735 & 755 & 680 & 875 & 620 & 720 \\
\hline 障害の状況 & $\begin{array}{l}\text { 左まひ } \\
\text { 縦手すりに } \\
\text { 寄り掛かる } \\
\text { (足こぎ) }\end{array}$ & $\begin{array}{l}\text { 上肢の力が } \\
\text { 強く便器移 } \\
\text { 乗等問題な } \\
\text { い }\end{array}$ & $\begin{array}{l}\text { 上肢の力が } \\
\text { 強く便器移 } \\
\text { 乗等問題な } \\
\text { い }\end{array}$ & $\begin{array}{l}\text { 右脚を欠損 } \\
\text { してるか } \\
\text { 左脚を軸に } \\
\text { 行動範囲大 }\end{array}$ & $\begin{array}{l}\text { 上肢の力が } \\
\text { 強く便器移 } \\
\text { 乗等問題な } \\
\text { い }\end{array}$ & $\begin{array}{l}\text { 導尿のため } \\
\text { 便器移乗な } \\
\text { : 座位変 } \\
\text { 換時に仰け } \\
\text { 反る }\end{array}$ & $\begin{array}{l}\text { 上肢の力が } \\
\text { 強く便器移 } \\
\text { 乗等問題な } \\
\text { W }\end{array}$ & $\begin{array}{l}\text { 手すりを使 } \\
\text { って立ち上 } \\
\text { がれば自立 } \\
\text { 歩行可 }\end{array}$ \\
\hline
\end{tabular}




\section{(3) 検証の前提}

(1)扉位置違いの検証

簡易型多機能トイレは一般に、一般便房と横並びのトイレブース 短辺側出入口設置タイプと、通路正面（突き当たり部）に出入口を 設けるトイレブース長辺側出入口設置タイプが最も普及しているこ とから、この 2 タイプで検証を行うことにした（図 2)。

(2)検証する空間寸法と被験者

本検証に先立ち、理学療法士 (1 名) と検証スタッフ(4 名)による模 擬検証を実施し、障害別・車い寸種別の目安となる最小空間寸法を 導き出した注 6)。その寸法は表 3 のとおりである。なお模擬検証の 対象となる被験者像はそれぞれの障害の症状を次のように定めた。

脊髄損傷者は「胸椎損傷」レベルを想定し、便器に移乗する際車 い寸の角度がある程度あっても、位置関係を整えながら移乗でき、 また上位腹筋はあるが下腹部腹筋がなく、体を起こして両手で作業 する場合は、どこかに掴まらなければならないレベルの人とした。

脳性まひ者は自分で電動車い寸を操作でき、立位等で大便器に移 乗できるレベルの人とした。

脳血管障害（片まひ）者は大便器移乗時に支持物（手すり）を持 って回転しながら着座できるレベルとした。

以上のような条件下で、また模擬検証を行い、その結果得られた 空間寸法を基に本検証を実施した（表 3）。

\section{4. 研究成果}

\section{(1) 短辺側出入口の検証}

短辺側出入口の片開き戸（外開き）は外部正面から向かって右側 が吊元、左側に扉開閉ハンドル及び錠（ロック）を取付けている。 簡易型多機能卜イレは一般トイレ内に設けられる広めの一般トイレ であるため、間口寸法 (短辺側) ・奥行寸法 (長辺側) 共に制約があ

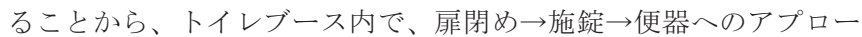

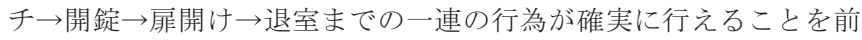
提に、利用可能最小寸法を測定した。

(1)脊髄損傷者の場合

・脊髄損傷者は大半の被験者がモジュール型車い寸を使用しており コンパクトな動きをするため奥行寸法 $1700 \mathrm{~mm}$ 以内で対応可能 な人が 6 名中 5 名であった。

\section{表 2 障害別被験者数}

\begin{tabular}{|l|r|c|c|c|}
\hline \multirow{2}{*}{ 障害名 } & \multicolumn{5}{|c|}{ 車いすの種類 } \\
\cline { 2 - 6 } & 手動 JIS 型 & モジュー型 & 電動式 & 計 \\
\hline 脳性まひ & 6 & & $2(1)$ & $8(1)$ \\
\hline 脊髄損傷 & - & $6(1)$ & & $6(1)$ \\
\hline 脳血管障害 & 1 & & & 1 \\
\hline 筋ジストロ & 1 & & & $16(3)$ \\
\hline \multicolumn{7}{|c|}{ 計 } & 8 & $6(1)$ & $2(1)$ & 16 内の数字は女性被験者数 \\
\hline
\end{tabular}

表 3 空間検証寸法の目安

注 : 表中 $(\mathrm{a} \times \mathrm{b})$ は図 2 参照

\begin{tabular}{|c|r|r|}
\hline (単位 : mm) & 短辺側入口 $(\mathrm{a} \times \mathrm{b})$ & 長辺側入口 $(\mathrm{a} \times \mathrm{b})$ \\
\hline 手動式 J I S 型 & $1,300 \times 1,900$ & $1,100 \times 2,000$ \\
\hline 手動式モジューN型 & $900 \times 1,700$ & $900 \times 1,800$ \\
\hline 電動式 & $1,250 \times 2,000$ & $1,300 \times 2,300$ \\
\hline
\end{tabular}

上記寸法は $50 \mathrm{~mm}$ ずつ可変させ検証・評価を行い求めた寸法である。
・被験者(10はモジュール型車い寸注 7 )使用者であるが、便器移乗の 際に便器に対し直角にアプローチしなければならず、他のモジュ 一ル型車い寸使用者より間口寸法が広がる要因になっている。

・被験者(14)便器に乗り移らずに「導尿」を行うため、車い寸上で 体位変換できる（仰け反る）スペースや導尿を行うための道具を 並べられる棚が、車い寸と平行した壁面に欲しい。

(2)脳性まひ者の場合

・被験者(3)普段は L 型手すりに体を預けて着脱衣するが、今回の 検証では大便器前に足を置くスペースが確保できなかったので、 車い寸から直接大便器の方に着座し、背もたれに背中を着けて仰 け反るようにして脱衣した。なお背もたれがない場合は車い寸上 で脱衣してから便器に移乗した（写真 2 ）。トイレブースの広さや 背もたれの有無によって着脱衣の方法が変わることが確認できた。 ・被験者(4)は必要とする間口寸法が最も大きいが $(1250 \mathrm{~mm}) 、$ 車い 寸が手動 J I S 型の中でも大きめのものであること、また扉に対 して車い寸を横付けしないと施錠等が行えないことが影響してい る (写真 3$)$ 。

・電動式車い寸被験者(7)は上体の動きが良く、狭いスペースでも 対応可能である（写真 4)。また間口を広げて検証したが、スペー スは狭くても広くても全く行動範囲は変わらない（写真 5)。

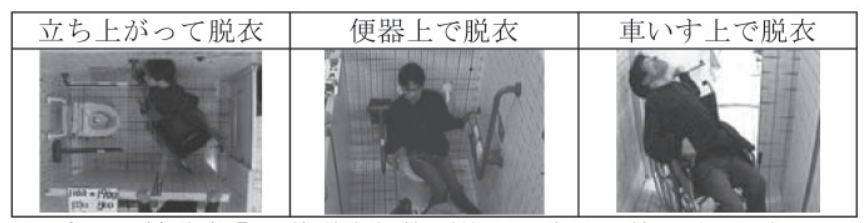

写真 2 被験者(3)の着脱衣行為（状況に応じて使い分ける）

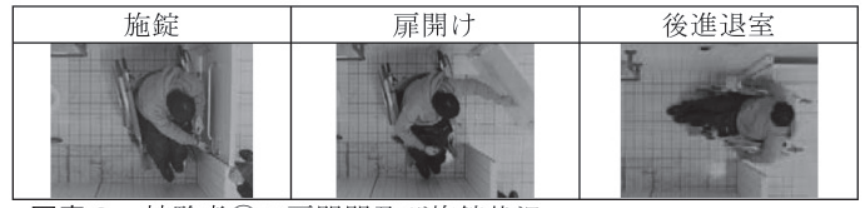

写真 3 被験者(4)の扉開閉及び施錠状況

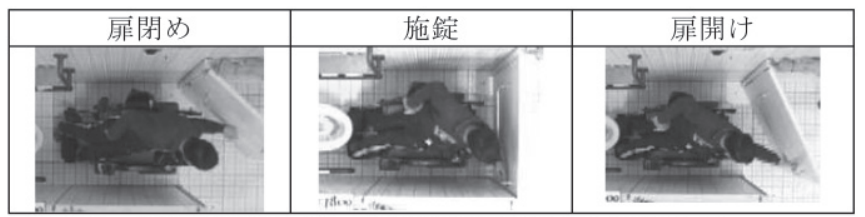

写真 4 被験者(7)の行為（非常に狭い空間でも対応可）

\begin{tabular}{|c|c|c|}
\hline 間口×奥行 $(\mathrm{mm})$ & 扉閉め & 便器移乗 \\
\hline $900 \times 2,000$ & & \\
\hline $1,100 \times 2,000$ & & \\
\hline $1,350 \times 2,000$ & -5 & \\
\hline
\end{tabular}

写真 5 被験者(7)の移乗行為（間口が広がっても位置不変） 
(3)筋ジス・脳血管障害者の場合

・JIS 型車いすで最も省スペースだったのは筋ジスの被験者16だが

$(900 \mathrm{~mm} \times 1750 \mathrm{~mm})$ 、比較的症状が軽く車い寸から降りて車い すを利用しながら扉閉め・施錠を行うので（写真 6 ）、さらに奥行 寸法を小さくし $900 \mathrm{~mm} \times 1700 \mathrm{~mm}$ を検証したところ、正面から 入室したが便器前の足置きスペースが確保できないと判断し、一 旦ブース外に出て後向きで入室した。その後立ち上がって車い寸 の横を通って便器に着座するが、通路・足置きスペースが殆ど確 保できず、使用できないと判断した。

(4)短辺側出入口タイプ最小空間評価方法と結果

入室から退室までの一連の動作を 5 段階で評価し、限られた検証 回数の中で以下に示寸評価 $\mathbf{\Delta}$ ○を把握して、切り返しが必要であ

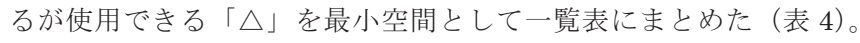

×：使用できない寸法

ム：何とか使用できるが相当困難な寸法

$\triangle: 2 \sim 3$ 回の切返しが生じるが使用できる寸法

○: スムースに使用できる寸法

（）：とりを感じる寸法

(5)考察〔各項目の（）内の数字は被験者 No を示す〕

被験者が空間検証において、使用可能と判断する基準として、

・便器移乗時に車い寸が便器に対し角度がとれること (3)(8)(10)

・前進退室するためブースで車い寸が回転できること (5)(11)(12)(13)(15)

・便器移乗時跳上げ手すり側にスペースが確保されること (11)

・ 小用時の補助備品置き台とカテーテル挿入時の車い寸座面前方へ の座り直しのための仰け反りスペースが確保されること (14)

・扉の開閉及び施錠が容易に行えること (1)(4)

・扉に対し車い寸が平行に停められること（2)

等が挙げられる。また被験者の大半を占めた脊髄損傷（モジュール 型車い寸）と脳性まひ（手動 JIS 型車いす）で大別すると、

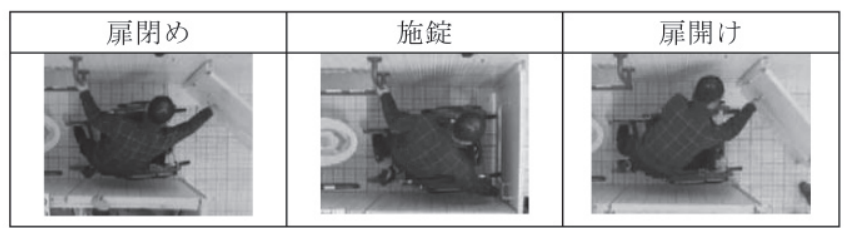

写真 6 被験者(16)の行為（車い寸に体を預けて扉閉め・施錠）

表 4 短辺側出入口の場合の最小空間寸法評価 $(\triangle)$

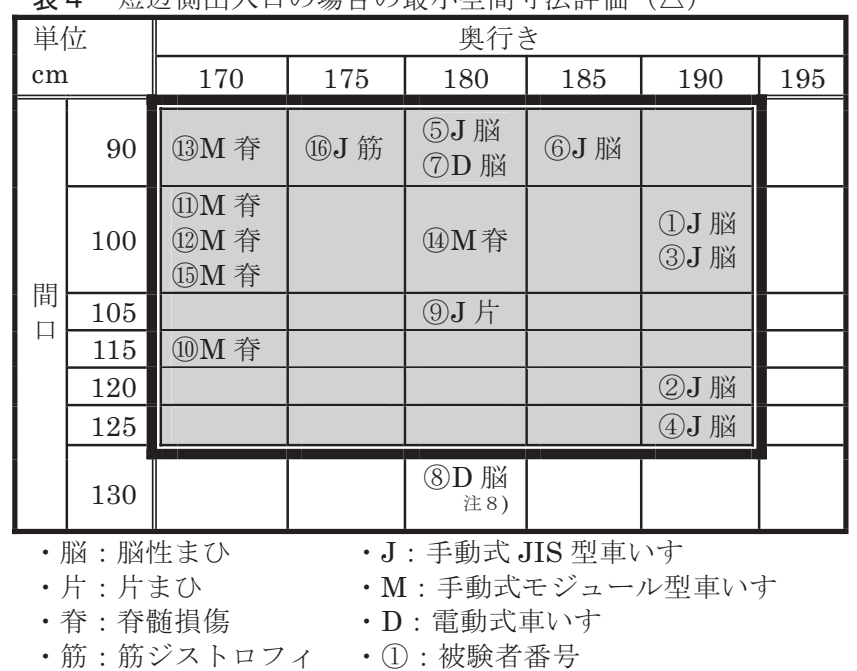

・脊髄損傷者の最小空間寸法 : $1,200 \mathrm{~mm} \times 1,800 \mathrm{~mm}$

・脳性まひ者の最小空間寸法 : $1,250 \mathrm{~mm} \times 1,900 \mathrm{~mm}$

と差があることが分かる。これは上肢の運動機能の差並びに使用車 い寸の動線の短さ(コンパクトな動き)が大きく影響している。

その他、スペースの広さに応じて、着脱衣する場所と方法が変わ る(例えば(3)）。あいはスペースが広がっても、一連の行為を行う 場所が全く変わらない（例えば(7)）等、同じ障害であっても症状の 違い、使用する車いすの違いによって動作並びに評価が異なること が分かった。

(6)要望点及び改善点

片開き戸の開閉・施錠に関しては、全ての被験者が操作に負担を 要していた。

・扉は自閉式がより良い（車い寸を操作しながら扉閉めは厳しい）

・扉の内側（便房内）に横長い握りバーを設置して欲しい（特に脳 性まひ者)

・ドアロックの開閉レバーを「長く」「大きく」して欲しい（同上） ・扉吊元側にドアロックを設けて欲しい（電動車いすは小回りが出 来ないため、扉を閉める動作の連続で施錠したい)

等の要望が被験者から出された。

以上のことから、簡易型多機能卜イレはスペースだけでなく、扉 の開閉方式及び施錠・開錠のし易さまで総合的に捉えていく必要が ある。

\section{(2) 長辺側出入口の検証}

長辺側出入口の片引き戸は外部正面から向かって右側に扉開閉八 ンドルと錠（ロック）を取付けている（扉は左側引き込みタイプ）。 検証手順・内容は短辺側出入口タイプと同様とする。

(1)脊髄損傷者の場合

・脊髄損傷の方はモジュール型車い寸の使用が多く、間口 $900 \mathrm{~mm}$ が 4 名、奥行き $1800 \mathrm{~mm}$ が 5 名と大半の被験者が省スペースで の行為が可能であった。

・但し、被験者(14)(2)短辺側出入口の検証で、便器に乗り移らずに 尿漏れパットを使って「導尿」を行うことが確認できた特異な例 であるが、導尿の準備で車い寸座面先端に座位移動するため仰け 反らなければならず奥行き寸法に大きく影響を与える（写真 7)。

(2)脳性まひの場合

・被験者(4)は車い寸が大型であり、入退室時に扉に対し車い寸が垂 直になるため間口寸法を大きくすることが必要である。

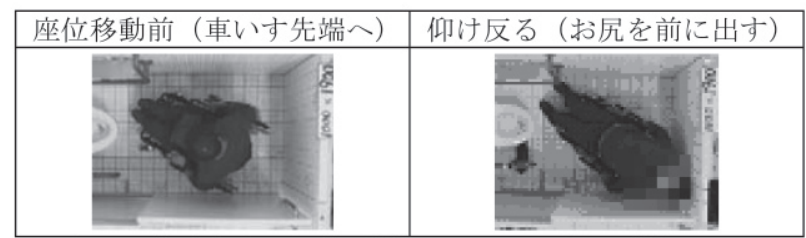

写真 7 被験者(14)の行為（導尿のための準備状態）

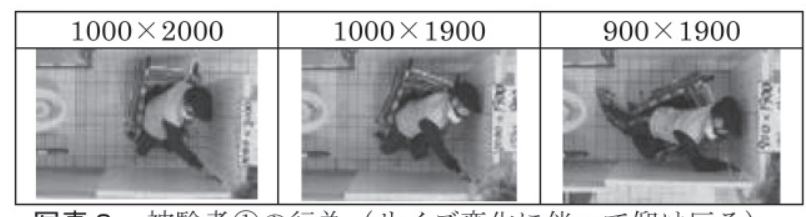

写真 8 被験者(1)の行為（サイズ変化に伴って仰け反る） 
・被験者(1)はブースのサイズによって車いすの回転動作が規制され るため、施錠時の車い寸停車位置によって体勢が大きく変わるこ とが確認できた（写真 8)。

・電動式車い寸の被験者(7) は上体の動きがよく、狭いスペースでも 判断し奥行寸法によって車い寸の停位置を決める。間口・奥行 が小さくなると車いすを動かさず体を仰け反らせ施錠（写真 9)

(3)筋ジス・脳血管障害者の場合

・被験者 (9)脳血管障害で便器移乗の際、便器に対し車い寸をほぼ 90 度でアプローチし、縦手すりに体を預けて着脱衣行為を行うた め、間口寸法が必要になる（写真 10）。間口寸法 $1,100 \mathrm{~mm}$ では 車い寸が斜めになり過ぎて角度が取れず、縦手すりに体を預ける ことができない。間口寸法 $1,200 \mathrm{~mm}$ では車いすから立ち上がっ た正面に縦手寸りがあるため、体を倒れ掛かるように預けること ができ脱衣が可能である。

(4)長辺側出入口タイプ最小空間評価方法と結果

評価内容（使用可能と判断する寸法）については前述の「短辺側 出入口タイプ最小空間評価」と同様、被験者は入室から退室まで の一連の動作を 5 段階で評価し、限られた検証回数の中で評価 $\Delta$ 〜○を把握し、切り返しは必要であるが使用できる「 空間として一覧表にまとめた（表 5)。

×：使用できない寸法

ム : 何とか使用できるが相当困難な寸法

$\triangle: 2 \sim 3$ 回の切返しが生じるが使用できる寸法

○: スムースに使用できる寸法

（）：ゆとりを感じる寸法

(5)考察〔各項目の（）内の数字は被験者 No を示す〕

長辺側出入口の場合、車い寸側面に扉が来るため扉の開閉動作 · 施錠動作に関する判断基準が短辺側出入口と少し異なる。また被験 者が使用可能とする判断基準に、便器への斜めアプローチ優先や便 器前足置きスペース確保優先等、間口寸法と奥行寸法のどちらを優 先するかに差が生じた。

(5) - 1 間口寸法を優先する意見

- 扉の開閉及び施錠のしやすい位置（扉を真正面に見る位置）に車 い寸が停められること(1)(4)(8)。

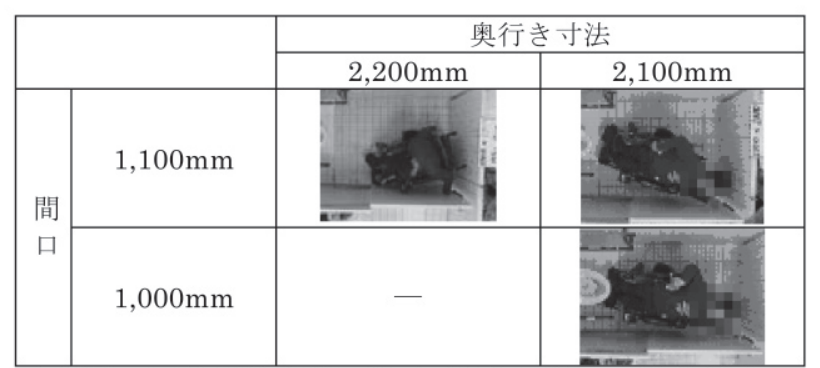

写真 9 被験者(7)の行為（サイズ変化に伴って仰け反る）

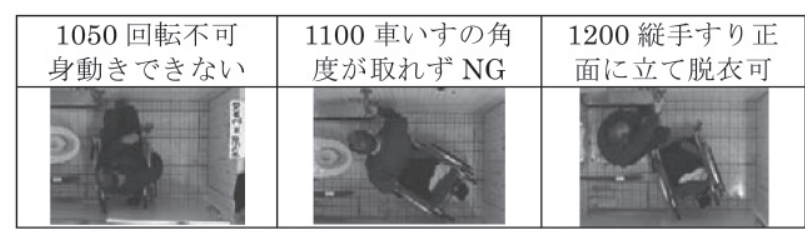

写真 10 被験者(9)の便器への移乗・脱衣状況
・車いすが壁や扉に当たらず回転でき前進退室ができること

(5)。

・便器に対し車いすを斜めに停められること (3)(8))。

(5) -2 奥行寸法を優先する意見

・便器前に足置きスペースの確保ができること (3)(6)(8))。

・車いす停め位置（扉に平行）による扉開閉・施錠のし易さ（7) 等が挙げられる。

(6)要望点及び改善点

長辺側出入口の片引き戸は、殆どの被験者が開き戸に比べて、開 閉しやすいと評価をしているが、以下のような要望が出された。

・車い寸の停め位置によって 1 回で引き戸を閉め切れないので、引 き戸の内側（便房内）に横長の握りバーを取り付けて欲しい。

・ドアロックの開閉レバーを「長く」「大きく」して欲しい。さらに ドアロックの位置をドア端部(従来とは逆の位置でブース中央部) にして欲しい（図 3)。

これらについては、引き戸の内側に横長の握りバーを取り付け、ド アロックを扉引き込み側に設けることで、大幅な改善が図れると判 断する。

\section{5. 結論}

今回の検証の主被験者であった脳性まひと脊髄損傷の障害種別に よる動作の違い、手動 JIS 型とモジュール型の車いすの種類による 違い、さらに車い寸操作技術の違い、身体の柔軟性（まひ等の度合 い）によって、ブース寸法に差が生じることが判明した。

結論として本検証で得られた表 4、表 5 の被験者ごとの利用可能 な最小空間寸法を検討寸ると、簡易型多機能卜イレの最小空間寸法 として、

- 短辺側出入口の場合 : $\mathrm{a}=1,250 \mathrm{~mm} \times \mathrm{b}=1,900 \mathrm{~mm}$ （表 4 網掛部）

- 長辺側出入口の場合 : $\mathrm{a}=1,150 \mathrm{~mm} \times \mathrm{b}=2,000 \mathrm{~mm}$ （表 5 網掛部） を推奨することができる注 9 。

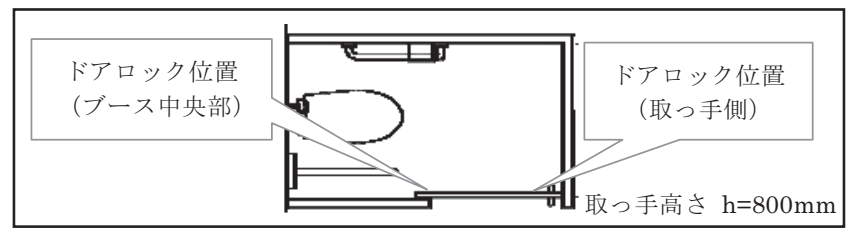

図 3 引き戸のドアロック位置

表 5 長辺側出入口の場合の最小空間寸法評価 $(\triangle)$

\begin{tabular}{|c|c|c|c|c|c|}
\hline \multirow{2}{*}{\multicolumn{2}{|c|}{$\begin{array}{l}\text { 単位 } \\
\mathrm{cm}\end{array}$}} & \multicolumn{4}{|c|}{ 奥行き } \\
\hline & & 180 & 190 & 200 & 210 \\
\hline \multirow{7}{*}{$\begin{array}{l}\text { 間 } \\
\text { 口 }\end{array}$} & 90 & $\begin{array}{l}\text { (12) } \mathrm{M} \text { 脊 } \\
\text { (13) } \mathrm{M} \text { 脊 } \\
\text { (15) } \mathrm{M} \text { 脊 }\end{array}$ & $\begin{array}{l}\text { (5) } J \text { 脳 } \\
\text { (1) } J \text { 脳 }\end{array}$ & & \\
\hline & 95 & (11) $\mathrm{M}$ 脊 & & (6) J 脳 & \\
\hline & 100 & & $\begin{array}{l}\text { (3) } \mathrm{J} \text { 脳 } \\
\text { (14) } \mathrm{M} \text { 脊 }\end{array}$ & & \\
\hline & 105 & & & (9) J 片 & \\
\hline & 110 & (16) J 筋 & & $\begin{array}{l}\text { (2) J 脳 } \\
\text { (8)D 脳 }\end{array}$ & (7)D 脳注 8) \\
\hline & 115 & (10) $\mathrm{M}$ 脊 & (4) $J$ 脳 & & \\
\hline & 120 & & & & \\
\hline \multicolumn{6}{|c|}{$\begin{array}{l}\text { ・脳 : 脳性まひ } \\
\text { ・片 : 片まひ } \\
\text { ・春 : 脊髄損傷 } \\
\text { ・筋 : 筋ジストロ }\end{array}$} \\
\hline
\end{tabular}


なお、検証時における被験者共通の要望として

・扉は開き戸、引き戸とも開閉を容易にするため、扉内側に横長の 握りバーを設置すること。

・ドアロックのレバーを「長く」「大きく」すること。

・ドアロックの位置を操作しやすい場所に設けること。

等が確認された。

\section{謝辞}

実験にご協力いただいた被験者の方々にこころより謝意を表し ます。また実験に際し貴重なアドバイスをいただいた河添竜四郎氏、 戸村哲次郎氏、江藤祐子氏に感謝いたします。

\section{注}

注1）多機能トイレとは、基本的に排泄行為に的を絞り、多様な機能（便器 · 手すり・背もたれ・オストメイト用流し・乳児用い寸・乳児用ベッド・ おむつ交換用ベッド等）を有したトイレであるが、車いす使用者の円滑 な利用を基本としている。

注2）平成 18 年 12 月にバリアフリー新法が施行され、バリアフリー新法及 び関係省令等に対応した建築設計標準を国土交通省が定めた。この建築 設計標準は、建築物のバリアフリー設計の際に考慮すべき包括的な考え 方や、実際の設計において地域性や用途に合わせ、建築物の利用が想定 される高齢者・障害者等のニーズや利用の実態に沿って設計するための ガイドラインとなるもの。

注3）簡易型多機能トイレとは、一般トイレのユニバーサルデザイン化を目的 に、一般トイレでの車い寸使用者等の利用を可能にした、やや広めの卜 イレのこと。乳児用い寸や乳児用ベッドが設けられる。

注4）注 2）バリアフリー新法の建築設計基準の簡易型多機能便房の項に、正 面から入る場合は幅 $80 \mathrm{~cm}$ 以上の出入口の確保、側面から入る場合は幅 $90 \mathrm{~cm}$ 以上の出入口の確保が必要と記されている。

注5）表 1 調査対象者の概要の乗車時最大長は（フットレストから出た）つま 先からハンドグリップ端までの寸法を、また乗車時最大幅はハンドリム 操作時の両肘先端間の寸法を指している。

注6）被験者が障害を持たれた方々であり、体力的な負荷を考慮し検証を効率 的に進めるために、障害者の移動に経験を有する理学療法士（1名）の 参加を得て、模擬検証を実施し検証開始時の目安寸法を見い出したもの
でバリアフリー新法建築設計標準で定められている $900 \mathrm{~mm} \times 1900 \mathrm{~mm}$ を基準に幅・奥行き共 $50 \mathrm{~mm}$ ずつ変化させて利用可能な最少空間寸法 を設定した。

手動モジュール型の場合は小型であり、多くの使用者が春髄損傷の方で あることから、小回りも十分可能との判断も加え、 $900 \mathrm{~mm} \times 1700 \mathrm{~mm}$ からスタートし、その寸法で利用可能と判断した。また手動 JIS 型の場 合は $1000 \mathrm{~mm} \times 1800 \mathrm{~mm}$ からスタートして、1300mm $\times 1900 \mathrm{~mm}$ で利 用可能と判断した。

注7）モジュール型車い寸とは、車輪の取付位置や車体の幅、レッグレスト、 アームレスト等の高さ・位置・形状等を後から変更できるよう、あらか じめ製作された各パーツモジュールにより組み上げられたもので、春䯣 損傷の人が多く使用している。

注8）表 4 の被験者(8)及び表 5 の被験者(7)は、短辺側出入口・長辺側出入口に おいて、間口寸法・奥行寸法それぞれに他の被験者に比べ空間寸法が $100 \mathrm{~mm}$ 大きくなっており、最小空間寸法の求めに対し影響をあたえて いる。電動車いすの操作特性（小刻みな切り返しが必要）を考慮すると より広めの車いす用トイレの利用者と位置付けた。

注9）今回の検証結果で一定の最小空間寸法を把握することができたが、扉や 取っ手の形状に配慮した使い易さの検証がさらに必要と考えている。

\section{参考文献}

1) 越川康夫他 1 名：トイレ利用シミュレーションによるトイレ空間の評価 に関する研究、日本建築学会大会学術講演梗概集、D-1、pp459-460, 1996.7 2) 田中直人他 3 名 : 視覚障害者による車い寸使用者向けトイレの利用に関 する研究、トイレ空間のユニバーサルデザインに関する基礎的研究、日本 建築学会大会学術講演梗概集、E-1、pp337-338, 2000.7

3) 後藤義明他 2 名: トイレ空間の壁に設置する設備機器の適正配置に関する 実験的検討、バイオメカニズム学術講演会予稿集、pp243-246、2002.10

4) 高橋儀平他 2 名：パブリックトイレの標準化に関する研究、その 5 大便 器まわりの手すり検証、日本建築学会大会学術講演梗概集、E-1、pp817-818、 2007. 7

5) 瀬谷知紀他 2 名：パブリックトイレの標準化に関する研究、その 4 操作系 設備のユーザー再検証、日本建築学会大会学術講演梗概集、E-1、pp809-810、 2006. 7

6) 難波明日香他 1 名：トイレ空間に関する実験的研究、床面積形状の違いと 照度の変化が印象評価に与える影響、日本建築学会大会学術講演梗概集、 E-1、pp811-812、2006. 7

2008年10月11日原稿受理，2009年 2 月24日採用決定） 